DOI: $10.2478 /$ aucft-2013-0023

\title{
THE INFLUENCE OF PARASITIC INFECTION ON THE BLOOD COUNT OF THE EXTENSIVELY REARED SHEEP
}

\author{
- short communcation -
}

\author{
Kristýna ŠIMÁK-LÍBALOVÁ*1, Miloslav ŠOCH*, Anna ŠIMKOVÁ*, \\ Kateřina ŠVEJDOVÁ*, Václav PÁLKA*, Luboš ZÁBRANSKÝ*, Bohuslav \\ ČERMÁK* \\ * University of South Bohemia in České Budějovice
}

\begin{abstract}
The article view on the effect of the extensive breeding conditions on health state of sheep in foothill areas of the South Bohemian region. Very negatively affects the health of sheep presence of parasitic infection in the herd. Among the factors indicative of the normal process of physiological functions and thus the health of sheep include haematologic and biochemical parameters of blood. Samples of blood and excrements were collected and divided by breeds of sheep and sampling time. It was done Faeces examination of excrements and was determined number of erythrocytes and leukocytes, haematocrit, haemoglobin, content of zinc and copper in blood and differential leucocytes count. Haematological and biochemical parameters were observed for all samples in the physiological range, despite the simultaneous parasitic contagions of examined animals.
\end{abstract}

Keywords: sheep, foothill region, haematological parameters, blood count

\section{INTRODUCTION}

The article view on the effect of the extensive breeding conditions on health state of sheep in foothill and mountain areas of the South Bohemian region.

${ }^{1}$ Department of Veterinary Sciences and Quality of Product, Faculty of Agriculture, University of South Bohemia in České Budějovice, Studentská 13, 37005 České Budějovice, Czech Republic. E-mail: kristy.kristyna@gmail.com.

Vol. XVII (2013), no.2 
The health state of animal is just one of the main factors affecting the economy and the profitability of farming in a challenging climate of foothill and mountain areas. Very negatively affects the health of sheep presence of parasitic infection in the herd even individuals. Among the factors indicative of the normal process of physiological functions and thus the health of sheep include hematologic and biochemical parameters of blood of animals. The blood examination offers important data in the view of some diseases, nutrional and immunological status discovery in the case of all species of farm animals (Mot et al., 2011). In order to provide a high quality sheep production a more information is need on their mineral requirements in relation to management system. Knowing the microelements status of the different sheep categories and interpreting test results correctly is of major importance for determining potential preventive arrangements (Brouček et al., 2009). Normal physiological values of various blood parameters of animals are affected by many factors such as age, sex, breed, season, altitude, climate, nutrition and lifestyle habits of the species state (Tripathi et al., 2008). These above mentioned factors confirm in their study (Šoch et al. 2010) by sheep kept in pasture farming system.

One of the most important blood parameters applicable for determining the health of the animal is haemoglobin. The amount of haemoglobin in the blood is directly dependent on the presence of its basic structural components in the diet and the body's ability to absorb these components. They are primarily proteins with amino acids (glycine and histidine), $\mathrm{Fe}, \mathrm{Cu}, \mathrm{Co}$, vitamin $\mathrm{B}_{12}$ and other substances necessary for the synthesis and recovery of hemoglobin in the body (Shenck and Kolb, 1991). Number of leukocytes in the blood is generically different and varies under the influence of physiological changes. The rise of leukocytes occurs when stress, physical stress and inflammatory processes. The decrease of leukocytes occurs when damaged cells divide their developmental effects of toxins in the absence of substances important for blood formation (e.g. vitamin $\mathrm{B}_{12}$ ). White blood cells by morphological parameters classified into granulocytes, monocytes and lymphocytes. Their ratio in the blood is species-specific (Williams, 1982). The different types of leukocytes have different functions such as neutrophil granulocytes phagocytize microorganisms especially in inflammatory processes. Eosinophilic granulocytes are used in allergic and parasitic diseases, phagocytize allergen-antibody complexes, in sheep with their relative numbers between $1-6 \%$ of the total number of white blood cells (Jelínek et al., 2003).

Vol. XVII (2013), no.2 
The important trace elements are copper and zinc, except for cobalt, iron, iodine, manganese and selenium, of course. Copper has a basic role in the metabolism and transition of iron in the body. It is an essential component of several enzymes such as ceruloplasmin, cytochrome $\mathrm{C}$ oxidase, lysil oxidase, superoxid dismutase, and tyrosinase, that are required to maintain host homeostasis (Swenson and Reece, 2004).

Zinc is important for the synthesis of proteins and nucleic acids, a number of catalytic, structural and regulatory functions, formation of skin structures and skeleton metabolism. In ruminants, it plays an important role in rumen fermentation processes, mainly cellulose digestion and formation of volatile fatty acids (Cao et al., 2000).

The deficiency of imbalance of minerals in the diet could lead to disturbances of metabolic function of organism (Šrejberová et al., 2008).

\section{MATERIALS AND METHODS}

The study was performed during the year 2012 in two selected herds of sheep, in Novohradské mountains and Blanský forest, which are highland areas of South Bohemia. It was the breed Suffolk and Wallachian sheep. All animals were healthy and in good conditions of hygiene and feeding. Samples of blood and excrements were collected at the beginning and the end of the grazing season and divided by breeds of sheep and sampling time. Excrements samples were collected and also samples of venous blood in the standing position from Vena jugularis into prepared sampling tubes. In the spring sampling were conducted in both breeds, in autumn only one breed, because of the lack of cooperation from the breeder. It was done Faeces examination of excrements and was determined number of erythrocytes and leukocytes, hematocrit, haemoglobin and content of zinc and copper in blood. It was also done differential leucocytes count. The presence of ova of parasites was monitored by flotation, which is most often used method for overall examination of parasites in the excrements, with this method it is possible to determine the occurrence both Protozoan and Helminth parasites. Collected blood samples were examined using hematological and biochemical analyzers. The differential leucocytes count was performed microscopic analysis of peripheral blood smears stained standardly by Pappenheim.

Basic statistical values were calculated in the program MS Office Excel.

Vol. XVII (2013), no.2 


\section{RESULTS AND DISCUSSIONS}

The values of the differential leukocytes count are in physiological range, although in one examined sample for the number of eosinophils was close to the limit of the physiological maximum 6\% (Jelínek et al., 2003), four other animals were just below the upper limit. The values of monocytes were on the limit of normal values reported by some authors in some samples. There is little consensus on margins of normal levels of blood parameters of sheep among the individual authors. For this reason, to compare this particular experiment were used the values reported Jelínek et al. (2003). A similar range of values reported for example Sova et al. (1990), Reece (1998), Bod'a et al. (1990).

Other haematological parameters taken from the blood of animals were within the physiological range. Also the range of values of trace elements zinc ( 0.90 to $\left.1.81 \mathrm{mg} . \mathrm{l}^{-1}\right)$ and copper $\left(0.75\right.$ to $\left.1.56 \mathrm{mg} . \mathrm{l}^{-1}\right)$ was physiological values reported by Jelínek et al. (2003) Zn 1-1.45 mg. $\mathrm{l}^{-1} \mathrm{Cu}$ and $0.8-10 \mathrm{mg} . \mathrm{l}^{-1}$ and animal health was not adversely affected by their lack. Some properties important for this investigation are summarised in Table 1.

Table 1. Haematological and biochemical parameters

\begin{tabular}{|c|c|c|c|c|c|c|c|c|}
\hline $\begin{array}{l}\text { Seaso } \\
\mathrm{n}\end{array}$ & Sample & Breed & $\begin{array}{l}\text { HB } \\
{\left[\mathrm{g} .1^{-1}\right]}\end{array}$ & $\begin{array}{l}\mathrm{HCT} \\
{\left[1.1^{-1}\right]}\end{array}$ & $\begin{array}{l}\mathrm{RBC} \\
{\left[\mathrm{T}^{-1} \mathrm{l}^{-1}\right]}\end{array}$ & $\begin{array}{l}\text { WBC } \\
{\left[G .1^{-1}\right]}\end{array}$ & $\begin{array}{l}\mathrm{Zn} \\
{\left[\mathrm{mg} \cdot \mathrm{l}^{-}\right.} \\
\left.{ }^{1}\right]\end{array}$ & $\begin{array}{l}\mathrm{Cu} \\
{\left[\mathrm{mg} .1^{1}\right.} \\
\left.{ }^{1}\right]\end{array}$ \\
\hline \multirow{12}{*}{ Spring } & 1 & $\mathrm{Su}$ & 109,8 & 0,30 & 6,1 & 6,5 & 1,29 & 1,27 \\
\hline & 2 & $\mathrm{Su}$ & 115,7 & 0,28 & 5,2 & 5,0 & 1,48 & 1,15 \\
\hline & 3 & $\mathrm{Su}$ & 121,2 & 0,31 & 5,7 & 3,1 & 1,40 & 1,45 \\
\hline & 4 & $\mathrm{Su}$ & 108,7 & 0,32 & 5,8 & 3,7 & 1,37 & 1,23 \\
\hline & 5 & $\mathrm{Su}$ & 133,5 & 0,35 & 6,5 & 4,4 & 1,14 & 1,16 \\
\hline & 6 & $\mathrm{Su}$ & 102,8 & 0,27 & 5,4 & 6,9 & 1,17 & 1,30 \\
\hline & 7 & $\mathrm{~V}$ & 108,0 & 0,33 & 5,5 & 6,49 & 1,26 & 0,92 \\
\hline & 8 & V & 109,6 & 0,31 & 6,2 & 4,60 & 0,90 & 0,75 \\
\hline & 9 & $\mathrm{~V}$ & 114,2 & 0,33 & 6,8 & 4,50 & 1,44 & 0,78 \\
\hline & 10 & $\mathrm{~V}$ & 113,6 & 0,29 & 5,8 & 5,50 & 1,54 & 1,11 \\
\hline & 11 & $\mathrm{~V}$ & 105,3 & 0,27 & 5,7 & 7,00 & 1,01 & 1,07 \\
\hline & 12 & $\mathrm{~V}$ & 106,5 & 0,26 & 5,5 & 4,80 & 1,07 & 1,04 \\
\hline \multirow[t]{4}{*}{ Fall } & 13 & $\mathrm{~V}$ & 150,1 & 0,35 & 7,8 & 5,20 & 1,47 & 1,27 \\
\hline & 14 & V & 126,5 & 0,34 & 7,4 & 5,20 & 1,20 & 1,56 \\
\hline & 15 & $\mathrm{~V}$ & 127,7 & 0,35 & 7,5 & 4,20 & 1,37 & 1,27 \\
\hline & 16 & $\mathrm{~V}$ & 141,8 & 0,43 & 9,0 & 7,10 & 1,37 & 1,21 \\
\hline
\end{tabular}

Vol. XVII (2013), no.2 


\begin{tabular}{|l|l|l|l|l|l|l|l|l|}
\hline & 17 & $\mathrm{~V}$ & 123,1 & 0,35 & 7,7 & 6,80 & 1,81 & 1,15 \\
\cline { 2 - 8 } & 18 & $\mathrm{~V}$ & 129,5 & 0,38 & 8,5 & 5,60 & 1,53 & 1,00 \\
\hline
\end{tabular}

Explanatory: Breed: Su- Suffolk, V- Walachien sheep,

HB- haemoglobin, HCT-haematocrit, RBC- erythrocytes, WBC- leukocytes, Znzinc, $\mathrm{Cu}$ - copper

The overall prevalence of parasites in the spring period collection is quite high, $75 \%$ of the investigated samples were positive, even when infection strength averaged rather weak. A total of three samples were completely negative. In the autumn, the numbers were much lower, but this trend is attributed to the fact that prior to our sampling took place in the herd antiparasitic precaution, which we unfortunately could not control. The most common presence was demonstrated in sort of Strongylida with 7 (38.9\%) positive samples. Following the occurrence of coccidiosis in 5 (27.8\%) positive samples. The number of positive samples of the sort Trichuris ovis was $3(16.7 \%)$. In one case was found Dicrocoelium dendriticum. Some properties important for this investigation are summarised in Table 2.

Table 2: Hematological parameters and the presence of parasites

\begin{tabular}{|l|l|l|l|l|l|l|}
\hline Season & Sample & Breed & $\begin{array}{l}\text { WBC } \\
{[\mathrm{G} / \mathrm{l}]}\end{array}$ & EO [\%] & FOI & Endoparasites \\
\hline \multirow{5}{*}{} & 1 & $\mathrm{Su}$ & 6,5 & 6 & ++ & DIC, STR \\
\cline { 2 - 8 } & 2 & $\mathrm{Su}$ & 5,0 & 2 & + & STR \\
\cline { 2 - 8 } & 3 & $\mathrm{Su}$ & 3,1 & 4 & ++ & STR, TRI \\
\cline { 2 - 7 } & 4 & $\mathrm{Su}$ & 3,7 & 5 & + & COC \\
\cline { 2 - 7 } & 5 & $\mathrm{Su}$ & 4,4 & 4 & - & TRI \\
\cline { 2 - 7 } & 6 & $\mathrm{Su}$ & 6,9 & 2 & 0 & \\
\cline { 2 - 7 } & 7 & $\mathrm{~V}$ & 6,5 & 3 & + & STR, COC \\
\cline { 2 - 7 } & 8 & $\mathrm{~V}$ & 4,6 & 2 & 0 & COC \\
\cline { 2 - 7 } & 9 & $\mathrm{~V}$ & 4,5 & 2 & - & TRI \\
\cline { 2 - 7 } & 10 & $\mathrm{~V}$ & 5,5 & 5 & + & STR \\
\cline { 2 - 7 } & 11 & $\mathrm{~V}$ & 7,0 & 5 & ++ & STR \\
\cline { 2 - 7 } & 12 & $\mathrm{~V}$ & 4,8 & 3 & 0 & \\
\hline \multirow{5}{*}{ Fall } & 13 & $\mathrm{~V}$ & 5,2 & 4 & - & COC \\
\cline { 2 - 7 } & 14 & $\mathrm{~V}$ & 5,2 & 1 & 0 & \\
\cline { 2 - 7 } & 15 & $\mathrm{~V}$ & 4,2 & 1 & 0 & \\
\cline { 2 - 7 } & 16 & $\mathrm{~V}$ & 7,1 & 5 & + & COC \\
\cline { 2 - 7 } & 17 & $\mathrm{~V}$ & 6,8 & 2 & - & STR \\
\cline { 2 - 7 } & 18 & $\mathrm{~V}$ & 5,6 & 3 & 0 & \\
\hline
\end{tabular}

Vol. XVII (2013), no.2 
WBC- leukocytes, EO- eosinophil; FOI= Force of infection: number of ova of parasite/signification $=0 / 0, \quad 1 /-, \quad$ under 5/+, 5-10/++, above 10/+++; Endoparasites: STR- Strongylida, TRI- Trichuris ovis, COC- coccidia, DICDicrocoelium dendriticum

\section{CONCLUSIONS}

Unfortunately, despite assumptions demonstrated correlation between parasitic infection and eosinophils respectively. leucocytes of the animals. The differences were not statistically significant. Reasons for not filling the hypothesis of the relationship between the presence of eosinophils and endoparasites in the samples, may be in a small number of observations, and of course the biological variability of experimental subjects. Removed number of samples I explained that it was the assumption of dependence between leukocytes and parasitic infection, which is in the literature already cited as a fact and therefore certainty that a smaller number of samples will be meaningful.

Comparison of the values of trace elements in the spring and autumn season confirm the good adaptation of sheep to pasture farming system, also good coverage of the nutritional needs with quality pasture. Similar findings have been published by other authors dealing with the issue of sheep in pasture farming systems.

\section{ACKNOWLEDGEMENTS}

Work was supported by project of the Grant Agency of the University of South

Bohemia (GAJU 020/2013/Z) and FRVŠ 1651/2012.

\section{REFERENCES}

1. Brouček, J., Šoch, M. \& Šrejberová, P. (2009). Effect of Different Environmental Factors on Selected Blood Minerals in sheep. Slovak Journal of Animal Science. 42(3), 451-150.

2. Bod'a, K. and Lebeda, M. (1972). Patologická fyziologie hospodářských zvírat. Praha, Czech Republic: Státní zemědělské nakladatelství.

3. Cao, J., Henry, P. R., Guo, R., Holwerda, R. A., Toth, J. P., Littell, R. C., Miles, R. D. \& Ammerman, C. B. (2000). Chemical characteristics and relative bioavailability of supplemental organic zinc sources for

Vol. XVII (2013), no.2 
poultry and ruminants. Journal of Animal Science. 78(8), 2039-2054. DOI: $10.1007 / \mathrm{s} 12011-012-9329-5$.

4. Jelínek, P. and Koudela, K. (2003). Fyziologie hospodárských zvírat. Brno, Czech Republic: MZLU v Brně.

5. Mot, D., Mot, T., Tirziu, E. \& Nichita, I. (2011). The Hematological Indexes Values in Sheep Correlated with Season. In Scientific Papers: Animal Science and Biotechnologies, 2011 (pp.177-179). Timisoara, Romania: AGROPRINT Timisoara, Romania.

6. Reece, W. O. (1998). Fyziologie domácích zvírat. Praha, Czech Republic: Grada Publishing.

7. Schenck, M. and Kolb, E. (1991). Základy fyziologickej chémie. Bratislava, Slovak Republic: Príroda.

8. Sova, Z. et al. (1990). Fyziologie hospodárských zvírat. Praha, Czech republic: Státní zemědělské nakladatelství.

9. Swenson, M. and Reece, W. O. (2004). Duke's Physiology of Domestic Animals. Twelfth edition, New York, USA: Comstock Publishing Associates.

10. Šoch, M., Šrejberová, P., Brouček, J., Kisac, P., Št’astná, J., Uhrinčat, M. \& Čermák, B. (2010). Evaluation of Hematological Parameters and Trace Elements in the Blood of Sheep. In Scientific Papers: Animal Science and Biotechnologies, 2010 (pp 524-527). Timisoara, Romania: AGROPRINT Timisoara, Romania.

11. Šrejberová, P., Šoch, M. \& Brouček, J. (2008). Relationship between copper and zinc on selected haematological parameters in beef and dairy cattle. Slovak Journal of Animal Science. 41(1), 42-45.

12. Tripathi, M. K., Momdal, D. \& Karim, S. A. (2008). Growth, haematology, blood constituents and immunological status of lambs fed graded levels of animal feed grade damaged wheat as substitute of maize. Journal of Animal Physiology and Animal Nutrition. 92(1), 7585. DOI: 10.1111/j.1439-0396.2007.00712.x.

13. Williams, C. K. (1982): The effects of molybdenum, iron and sulphur on copper metabolism and physiology of sheep. The Journal of Agricultural Science. 9: 99(2), 107-113.

Vol. XVII (2013), no.2 